Журнал«Герспективитаінновації наукиљ

(Серія«Гедагогіка», Серія«ГТихологія», Серія «Медицин»»

№2(7) 2022

УДК 378:373.2.011.3-051].014.6:005.642.4

https://doi.org/10.52058/2786-4952-2022-2(7)-220-230

Венгловська Олена Анатоліївна кандидат педагогічних наук, доцент кафедри педагогіки та психології, Київський університет імені Бориса Грінченка, вул. Бульварно-Кудрявська, 18/2, м. Київ, 04053, тел.: (044) 295-35-24, https://orcid.org/ 0000-0002-0456-7667

Куземко Леся Валентинівна кандидат педагогічних наук, доцент кафедри педагогіки та психології, Київський університет імені Бориса Грінченка, вул. Бульварно-Кудрявська, 18/2, м. Київ, 04053, тел.: (044) 295-35-24, https://orcid.org/0000-0003-3070-6322

Новик Ірина Михайлівна кандидат педагогічних наук, старший викладач кафедри педагогіки та психології, Київський університет імені Бориса Грінченка, вул. Бульварно-Кудрявська, 18/2, м. Київ, 04053, тел.: (044) 295-35-24, https://orcid.org/0000-0002-1366-7387

\title{
ПІДГОТОВКА МАЙБУТНІХ ВИХОВАТЕЛІВ ДО ВИМІРЮВАННЯ ЯКОСТІ ОСВІТНЬОГО ПРОЦЕСУ В ЗАКЛАДІ ДОШКІЛЬНОЇ ОСВІТИ
}

Анотація. У статті висвітлено особливості фахової підготовки майбутніх вихователів до вимірювання якості освітнього процесу в закладах дошкільної освіти. За результатами аналізу професійного стандарту за професією «Вихователь закладу дошкільної освіти» виокремлено професійні компетентності (прогностична, організаційна, оцінювально-аналітична, предметно-методична, проєктувальна, педагогічне партнерство) та трудові функції (організація, забезпечення та реалізація освітнього процесу; участь у створенні, підтримці та розвитку здорового, безпечного, розвивального, інклюзивного освітнього середовища; партнерська взаємодія з учасниками освітнього процесу; професійний розвиток та самовдосконалення), що $€$ визначальними у забезпеченні якості дошкільної освіти. Встановлено, що виокремленні компетентності та трудові дії є суголосні індикаторам якості тих методик, що широко застосовуються у зарубіжному освітньому просторі, однією з яких є методика Early Childhood Environment Rating Scale (ECERS-3). За результатами теоретичних студій розроблено рекомендації щодо вдосконалення змістово-методичного забезпечення навчальних дисциплін i педагогічних практик щодо формування у майбутніх вихователів умінь вимірювати якість освітнього процесу в закладі дошкільної освіти за визначеними підшкалами міжнародної методики Early Childhood Environment Rating Scale (простір і вмеблювання, повсякденні практики особистого догляду, мовлення та грамотність, види навчально-пізнавальної діяльності, взаємодія і 
структурування програми). Вони органічно поєднують вимоги до професійної підготовки педагогів у галузі дошкільної освіти, а також якості облаштування освітнього простору для активного, безпечного, всебічного, індивідуального розвитку дітей дошкільного віку.

Ключові слова: підготовка майбутніх вихователів; вимірювання якості освітнього процесу; Early Childhood Environment Rating Scale (ECERS-3); дошкільна освіта; професійні компетентності; трудові дії.

Venhlovska Olena Anatoliivna $\mathrm{PhD}$ in Pedagogy, Associate Professor at the Department of Pedagogy and Psychology, Borys Grinchenko Kyiv University, Bulvarno-Kudriavska St., 18/2, Kyiv, 04053, tel.: (097) 424-35-90, https://orcid.org/0000-0002-0456-7667

Kuzemko Lesya Valetynivna, $\mathrm{PhD}$ in Pedagogics, Associate Professor of the Department of Pedagogy and Psychology Borys Grinchenko Kyiv University, Kyiv, Bulvarno-Kudryavska St., 18/2, Kyiv, 04053, tel.: (044) 295-35-24, https://orcid.org/0000-0003-3070-6322

Novyk Iryna Mykhailivna, $\mathrm{PhD}$ in Pedagogy, Senior Lecturer of the Department of Pedagogy and Psychology of the Pedagogical Institute, Borys Grinchenko Kyiv University, Bulvarno-Kudryavska St., 18/2, Kyiv, 04053, tel.: (044) 295-35-24, https//orcid.org/ 0000-0002-1366-7387

\section{PREPARATION OF FUTURE EDUCATORS FOR QUALITY MEASUREMENT OF THE EDUCATIONAL PROCESS IN PRESCHOOL EDUCATION INSTITUTION}

Abstract. In this article highlighted features of professional preparation of future educators for quality measurement of the educational process in preschool education institutions. According to the analysis of the professional standard by profession «Educator of preschool education institution» singled out professional competencies (prognostic, organizational, evaluative-analytical, subject-methodical, projective, pedagogical partnership) and labor functions (organization, provision and implementation of the educational process: participation In creation, supporting and developing of healthy, safe, educational, inclusive educational environment; partnership interaction with participants of the educational process; professional development and self-development), which are decisive in providing of quality assurance of preschool education. Determined, that identified competencies and labor actions corresponds to quality indicators of those methodologics, that widely used in foreign educational space, one of which is methodology Early Childhood Environment Rating Scale (ECERS-3). According to the results of theoretical studies developed recommendations for improving the content-methodological support of educational disciplines and pedagogical practices for formation in future educators 
skills of quality measurement of educational process in preschool education institution according to certain subscales of international methodology Early Childhood Environment Rating Scale (space and furnishings, daily personal care practices, speech and literacy, types of educational and cognitive activities, interaction and program structuring). They organically combine requirements for professional training of educators in preschool education field, as well as quality of arrangement of educational space for active, safe, comprehensive, individual development of preschool children.

Keywords: preparation of future educators, quality measurement of educational process; Early Childhood Environment Rating Scale (ECERS-3); preschool education; professional competencies; labor actions.

Постановка проблеми. Одним із важливих кроків на шляху забезпечення якісної і доступної дошкільної освіти в Україні є запровадження стандартизації та постійнодіючого моніторингу іiі якості 3 урахуванням європейського та національного досвіду. Наразі розроблено і здійснюється імплементація низки нормативних документів: оновленого Базового компоненту дошкільної освіти (Державний стандарт дошкільної освіти, 2021) [1]; затверджених професійних стандартів «Вихователь закладу дошкільної освіти» (наказ Мінекономіки від 19.10.2021 № 755-21) [10], «Керівник (директор) закладу дошкільної освіти» (наказ Мінекономіки від 28.09.2021 № 620-21) [11]; підготовлено проєкт Закону України «Про дошкільну освіту» [9] та ін. Питання якісної доступної дошкільної освіти внесено до пріоритетних завдань Програми Уряду [8]. У цих документах якість дошкільної освіти визначається як комплексне явище, що охоплює заходи для досягнення результатів освітньої діяльності, поліпшення умов закладу дошкільної освіти (далі - ЗДО) для особистісного розвитку дитини. До показників якості відноситься також структура дошкільної освіти, практики і результати надання освітніх послуг [4]. Відтак, можемо констатувати значний вектор змін, що нині відбуваються в освіті України, спрямованих на оновлення іiі нормативної бази та розроблення нових освітніх стандартів, що визначають спектр компетентностей, якими мають володіти педагоги, реалізуючи трудові функції. У зазначеному контексті актуальності набувають питання удосконалення змісту професійної підготовки майбутніх вихователів дітей дошкільного віку, формування їхньої готовності до організації та вимірювання якості освітнього процесу в закладах дошкільної освіти.

Зазначимо, що здатність вихователів організовувати освітній процес, аналізувати результати розвивальної діяльності, проєктувати змістове наповнення середовища є одним із показників якості дошкільної освіти, а отже готовність вихователів до такого виду діяльності необхідно формувати ще на етапі їхнього навчання у закладі вищої освіти.

Аналіз останніх досліджень і публікацій. Проведений теоретичний аналіз засвідчив, що питання підготовки майбутніх педагогів до виконання трудових дій, зокрема і вимірювання якості освітнього процесу в ЗДО, є предметом 
дослідження як українських, так i зарубіжних учених. Окремі аспекти досліджуваного процесу актуалізовано у наукових розвідках Г. Іванюк, О. Венгловської, Є. Антипіна, Л. Куземко, І. Новик, де автори формування у майбутніх вихователів здатності та готовності до такого виду діяльності розглядають крізь призму складників (аксіологічний, пошуково-дослідницький, рефлексійний, навички XXI століття) їхнього особистісно-професійного розвитку [5; 6]. У дослідженнях С. Слюсарук-Літвін акцентується увага на професійно-педагогічній підготовці майбутніх фахівців в умовах сьогодення [12], а специфіку підготовки майбутніх вихователів та подальший вплив на якість дошкільної освіти розкрито у дослідженнях О. Дурманенко [3].

У контексті реалізації мети пропонованої статті заслуговують на увагу праці зарубіжних дослідників, які звертають увагу на значенні діагностичних інструментів для вимірювання якості дошкільної освіти, зокрема фокусують увагу на методиках, що є продуктивними у міжнародному освітньому просторі. Таким інструментом, що нині впроваджується в дошкільній освіті України $\epsilon$ методика Early Childhood Environment Rating Scale (ECERS-3), що спрямована на вивчення якості освітнього процесу кожного ЗДО в Україні [2]. Студіювання праць дослідників сприяє розумінню того, що пропонований інструмент має культурні відмінності та особливості впровадження 3 урахуванням освітніх традицій кожної країни. Так, у наукових розвідках S. Garvis, S. Sheridan, P. Williams, та E. Mellgren висвітлено досвід впровадження ECERS-3 у дошкільній освіті Швеції [15]. У публікаціях L. Sakai, M. Whitebook, A. Wishard та Howes [16] репрезентовано порівняльний аналіз між першою (ECERS-R) та наступними версіями (ECERS-3) шкал оцінювання якості дошкільної освіти.

У теоретичних виосновуваннях M. Burchinal, A. Auger, G. Farkas, M. Burchinal, G. Duncan i D. Vandell ключовою $є$ теза щодо усвідомлення педагогами важливості застосування ECERS-3 для вимірювання якості освітнього процесу в закладі дошкільної освіти, оскільки вона дозволяє отримати об'єктивні дані про форми взаємодії 3 дітьми, наявні умови для розвитку інтересів дітей, формування мотивації для подальшого особистого професійного зростання самих педагогів [14]. Педагогічні працівники орієнтуючись на міжнародні стандарти якості дошкільної освіти за методикою ECERS-3 зможуть створити і забезпечити якісне, безпечне освітнє середовище для всебічного розвитку дітей дошкільного віку [13]. Відтак, виникає потреба в оновленні змістового забезпечення навчальних дисциплін контентом, що спрямований на формування готовності майбутніх вихователів до такого виду діяльності.

Мета статті полягає в розкритті практичних аспектів професійної підготовки майбутніх вихователів до вимірювання якості освітнього процесу в закладі дошкільної освіти із застосуванням продуктивних, валідних i об'єктивних міжнародних інструментів.

Виклад основного матеріалу. Проблему підготовки вихователів до вимірювання якості освітнього процесу в ЗДО актуалізують результати 
пілотного етапу моніторингового дослідження 3 оцінювання якості освітнього процесу в закладах дошкільної освіти України із застосуванням методики ECERS-3, що був проведений в 2021 році [7]. Під час пілотного етапу найменшу кількість балів набрали такі параметри як: «Візуальне оформлення простору, пов'язане 3 дітьми» - 1,54; «Використання персоналом книжок у роботі 3 дітьми» - 1,28; «Заохочення дітей до користування книжками» - 1,91; «Знайомство $з$ друкованим текстом» - 1,0; «Мистецтво» - 1,88; «Музика та рух» - 1,65; «Кубики» - 1,28; «Математичні матеріали та види діяльності» - 1,35; «Розуміння зображених чисел» - 1; «Сприяння прийняттю різноманітності» - 1; «Правильне використання технологій» - 1,05. Загальна оцінка за шістьма підшкалами (3,05 бала з максимальних 7 балів) доводить нагальну необхідність ознайомлення вихователів, які вже працюють в ЗДО і тих, які навчаються в закладах вищої освіти за спеціальністю «Дошкільна освіта», 3 показниками індикаторів зазначеної методики.

3 цією метою нами здійснено теоретичний аналіз змісту професійних стандартів за професією «Вихователь закладу дошкільної освіти», виокремлено професійні компетентності та трудові функції, сформованість яких забезпечуватиме якість дошкільної освіти у розрізі стандартів якості за методикою ECERS-3, та розроблено рекомендації щодо їхнього формування. До професійних компетентностей, які уможливлюють виконання вихователями зазначених вище трудових дій належать: прогностична, організаційна, оцінювально-аналітична, предметно-методична, проєктувальна, педагогічне партнерство.

У професійному стандарті за професією «Вихователь закладу дошкільної освіти» (наказ Мінекономіки від 19.10.2021 № 755-21) подано опис умінь та навичок, що мають бути сформовані у межах виокремлених компетентностей, зокрема зазначено, що: «Вихователь має володіти здатністю здійснювати та інтерпретувати результати моніторингу якості освітньої діяльності для адаптації та коригування освітнього процесу відповідно до можливостей та потреб здобувачів освіти, зокрема, обирати відповідні цілям моніторингу критерії, індикатори, методи моніторингу якості освітньої діяльності» [10].

Аналіз змісту професійних компетентностей та трудових функцій вихователя ЗДО, що зазначені у профстандарті, доводить їхню суголосність із переважною більшістю параметрів методики ECERS-3, що визначають якість дошкільної освіти. Трудова функція «Організація, забезпечення та реалізація освітнього процесу» характеризує здатність фахівця забезпечувати якість освіти за підшкалою «Простір i вмеблювання». А саме: забезпечення належної організації внутрішнього простору ЗДО, що відповідає віковим та індивідуальним потребам дітей; облаштування у групових кімнатах i приміщенні ЗДО осередків за інтересами (читацький, художній, експериментування, усамітнення тощо); візуальне оформлення простору пов'язаного $з$ дітьми (індивідуалізовані мистецькі роботи та світлини дітей, колективні панно та ін.); організація безпечного та розвивального простору для 
розвитку великої моторики (музична та спортивна зали, ігрові майданчики, стадіон тощо).

Трудова функція за стандартом «Участь у створенні, підтримці та розвитку здорового, безпечного, розвивального, інклюзивного освітнього середовища» розкриває здатність вихователя до забезпечення якості освіти за підшкалою «Повсякденні практики особистого догляду». Це відповідальне ставлення педагогів до дотримання санітарно-гігієнічних норм під час повсякденних практик у ЗДО, здійснення постійного нагляду за безпекою дітей, зокрема це: миття і дезінфекція поверхонь, дотримання дітьми процедури миття рук до та після вживання їжі, надання дітям чистих харчових продуктів, постійний нагляд за безпечною поведінкою дітей у приміщенні закладу та на свіжому повітрі.

Трудова функція «Партнерська взаємодія 3 учасниками освітнього процесу» суголосна $з$ характеристикою показників якості дошкільної освіти за підшкалою «Взаємодія» методики ECERS-3. Вона передбачає взаємодію вихователів 3 дітьми в такий спосіб, який сприяє особистісному розвитку кожної дитини 3 урахуванням ii індивідуальних відмінностей. За цими компонентами якість освітнього процесу визначається здатністю персоналу ЗДО спілкуватися 3 дітьми на засадах поваги та ввічливості; реалізовувати індивідуальний підхід (реагувати на інтереси і здібності дітей, дозволяти дітям використовувати матеріали для ігор на власний розсуд, виділяти час для вільних ігор дітей тощо); створювати умови для позитивної взаємодії й набуття дітьми соціальних навичок (розуміння та дотримання правил, повага до почуттів та емоцій інших, навички залагоджувати конфлікти).

Трудова функція «Професійний розвиток та самовдосконалення» співзвучна з параметром «Правильне використання технологій», де передбачено використання IKT засобів (інтерактивні дошки; комп’ютери/ноутбуки; ігрові приставки; планшети) для стимулювання творчості або фізичної активності дітей (наприклад, творча програма 3 малювання на планшеті; відео уроків танців/аеробіки), а також 3 метою підтримки та розширення пізнавальних інтересів дітей; оцінювання персоналом доцільності відеоматеріалів і відеоігор, які пропонує сам педагога, так і тих матеріалів, які діти можуть приносити 3 дому.

Аналіз професійного стандарту за професією «Вихователь закладу дошкільної освіти» засвідчив потребу введення у зміст фахової підготовки майбутніх вихователів тем, що спрямовані на формування їхніх здатностей до вимірювання якості освітнього процесу в ЗДО 3 використанням методики ECERS-3. Зазначимо, що професійна підготовка може здійснюватись як у процесі вивчення навчальних дисциплін, так під час проходження навчальних практик. Так, освітньо-професійна програма 012 «Дошкільна освіта» першого (бакалаврського) рівня вищої освіти за якою навчаються здобувачі вищої освіти у Київському університеті імені Бориса Грінченка (https://kubg.edu.ua/images/ stories/Departaments/vstupnikam/pi/OPP_bak_DO_012.00.01.pdf) спрямована на формування у майбутніх фахівців із дошкільної освіти загальних і спеціальних 
(предметних, фахових) компетентностей, що є основоположними у формуванні їхніх здатностей до вимірювання якості освітнього процесу в ЗДО. Таким чином, у перебігу залучення здобувачів вищої освіти до різних видів навчальної діяльності системно та комплексно реалізуються завдання щодо формування здатності до планування, складання прогнозів, умінь передбачати наслідки власної професійної та інноваційної діяльності, здійснювати міжособистісну взаємодію, розробляти індивідуальну програму розвитку дітей раннього та дошкільного віку 3 урахуванням принципу дитиноцентризму, вікових та індивідуальних особливостей, здійснювати управління якістю освітнього процесу в ЗДО.

Проілюструємо особливості формування у майбутніх вихователів здатностей до вимірювання якості освітнього процесу в закладах дошкільної освіти на прикладі вивчення інтегрованої навчальної дисципліни «Педагогіка» (змістовий модуль: «Педагогіка дошкільна», «Інклюзивна освіта», «Педагогічне партнерство») та проходження навчальних практик.

Так, навчальною програмою змістового модуля «Педагогіка дошкільна» передбачено теми, що спрямовані на оволодіння студентами необхідними компетентностями щодо планування i організації різних форм навчальнопізнавальної діяльності дітей дошкільного віку, особливостей планування освітнього процесу в ЗДО. Відтак, важливо, щоб у контексті вивчення цих тем майбутні вихователі засвоїли сутність підшкал, параметрів та індикаторів, що $\epsilon$ складовими методики ECERS-3, оволоділи інструментами вимірювання їх якості. До прикладу, під час засвоєння студентами теми щодо особливостей залучення дітей дошкільного віку до побутових процесів необхідно акцентувати увагу на функціях вихователя щодо навчання дітей допомоги персоналу сервірувати стіл, прибирати за собою, етикету поводження за столом та споживання їжі (правильне користування серветками, виделкою і столовим ножем тощо). Означені характеристики є складовими підшкали «Повсякденні практики особистого догляду» [2, с. 38].

У перебігу вивчення теми «Форми організації навчально-пізнавальної діяльності у закладі дошкільної освіти» важливо, щоб майбутні вихователі не лише оволоділи змістом різних форм організації життєдіяльності дітей, а й обговорювали питання щодо особистісного розвитку дітей під час різних видів навчально-пізнавальної діяльності, зокрема розвитку дрібної моторики дітей, що досягається під час використання будівельного матеріалу (різні види кубиків), матеріалів для занять мистецтвом (фломастери, ножиці, кольорова крейда, олівці тощо), матеріалів для розвитку рухливості пальців рук (нитка та великі намистини, дошки з отворами та вкладками відповідних форм, заготовки для вишивання, мозаїка, пазли) тощо [2, С. 57-77]. 3 цією метою під час практичних занять варто передбачити завдання, що спрямовані на формування у майбутніх педагогів умінь аналізувати відповідність матеріалу віку, індивідуальним особливостям та інтересам дітей, тематиці різних видів розвивальної діяльності дітей дошкільного віку. За результатами аналізу 
складати плани щодо покращення освітнього процесу з урахуванням результатів спостережень.

Під час вивчення змістового модуля «Інклюзивна освіта» студентам варто пропонувати завдання щодо вивчення умов у ЗДО, необхідних для організації безбар'єрного освітнього середовища для осіб із особливими освітніми потребами. Зокрема, проаналізувати відповідність простору ЗДО вимогам універсального дизайну (ширина дверних отворів (не менше 90 см), висота дверних порогів, наявність різних способів виклику персоналу із застосуванням дистанційних засобів, вільного безбар'єрного доступу до осередків діяльності за інтересами) та співвіднести їх 3 індикаторами методики ECERS-3, розробити рекомендації щодо облаштування групової кімнати, наприклад зонування групового приміщення (відділеність тихих та гамірних ігрових осередків, наявність не менше п'яти різних осередків діяльності за інтересами дітей, вільний доступ усіх дітей до наявних осередків тощо).

Важливою складовою професійного вивищення майбутніх вихователів $\epsilon$ їхня здатність до налагодження з учасниками освітнього процесу продуктивної взаємодії на засадах педагогічного партнерства. Відтак, співпраця між педагогами, дітьми та їнніми батьками є одним із показників забезпечення якості освітнього процесу. Це актуалізує потребу у поглиблені змісту навчальної дисципліни «Педагогічне партнерство» завданнями, що розкривають питання реалізації індивідуального підходу до особистісного розвитку дитини дошкільного віку, особливостей організації міжособистісної взаємодії, застосування практик, що спрямовані на підтримку дитини, розвиток iі соціальних умінь та навичок, розроблення правил під час виконання спільних завдань [2, с. 79-87].

Зауважимо, що формування готовності майбутніх вихователів до вимірювання якості освітнього процесу в закладі дошкільної освіти є можливим за умови поєднання теорії та практики. У Педагогічному інституті Київського університету імені Бориса Грінченка студенти спеціальності «Дошкільна освіта» проходять навчальну практику, починаючи з першого курсу. Відповідно до навчального плану та програми практики майбутні педагоги вивчають особливості психолого-педагогічного супроводу організації розвивальної діяльності у різних типах закладів дошкільної освіти. Проходженню практики передують майстер-класи, під час яких студенти мають можливість удосконалити вміння, що спрямовані на розв'язання завдань практики, у тому числі й тих умінь, що висвітлюються у пропонованій статті. Так, у перебігу проходження майстер-класів майбутні вихователі засвоюють показники відповідності приміщення вікової групи ЗДО, простору для розвитку великої моторики дітей показникам та індикаторам якості, проєктують змістове наповнення осередків діяльності, місця для усамітнення, вивчають відповідність обладнання віковим, індивідуальним особливостям дітей, їхнім інтересам. Під час проходження практики у закладі дошкільної освіти майбутні вихователі вчаться фіксувати результати спостереження у спеціальних бланках та 
протоколах, узагальнювати результати, робити висновки, розробляти пропозиції щодо покращення розвивальної діяльності 3 дітьми дошкільного віку, наповнення осередків діяльності.

Висновки. Таким чином, під професійною підготовкою майбутніх вихователів до вимірювання якості освітнього процесу в ЗДО вбачаємо комплексний, систематичний процес оволодіння здобувачами вищої освіти компетентностями, що уможливлюють реалізацію ними трудових дій, пов'язаних із здатністю досліджувати освітній процес у закладі дошкільної освіти, узагальнювати та фіксувати результати вивчення, робити прогнози щодо покращення якості дошкільної освіти.

Досліджено, що формування означеного компонента професійної підготовки здійснюється у відповідності до вимог професійного стандарту за професією «Вихователь дітей дошкільного віку», де визначено перелік компетентностей та трудових умінь, що спрямовані на здатність педагогів забезпечувати та вимірювати якість дошкільної освіти 3 урахуванням прогресивних міжнародних методик, зокрема й методики ECERS-3.

Зазначимо, що перспективами подальших наукових розвідок можуть стати питання щодо моніторингу рівня підготовки майбутніх вихователів до вимірювання якості освітнього процесу в ЗДО з використанням методики ECERS-3.

\section{Лimepamypa:}

1. Базовий компонент дошкільної освіти (Державний стандарт дошкільної освіти). 2021. URL: https://mon.gov.ua/storage/app/media/rizne/2021/12.01/Pro_novu_redaktsiyu\%20Bazovoho\%20 komponenta\%20doshkilnoyi\%20osvity.pdf.

2. Гармс Тельма, Річард М. Кліффорд, Деббі Краєр. Шкала оцінювання якості освітнього процесу в закладах дошкільної освіти. Третє видання (ECERS-3) / пер. 3 англ. О. Тільна. Харків: Вид-во «Ранок», 2020. 116 с.

3. Дурманенко О. Оцінювання якості дошкільної освіти як складник професійної підготовки майбутніх вихователів. Acta Paedagogica Volynienses. №1. 2021. C.16-22. URL: http://journals.vnu.volyn.ua/index.php/pedagogy/article/view/53.

4. Свропейська рамка якості раннього розвитку і дошкільної освіти, 2019. URL: https://eur-lex.europa.eu/legal-content/EN/TXT/PDF/?uri=CELEX:32019H0605(01)\&rid=4

5. Іванюк, Г. І., Венгловська, О. А., Антипін, С. Б. Особистісно-професійний розвиток майбутніх педагогів у процесі навчальних практик. Неперервна професійна освіта: теорія $\mathrm{i}$ практика. № 2 (63). 2020. С. 25-34.

6. Куземко Л. В., Новик, І. М. Сучасні аспекти особистісно-професійного розвитку майбутніх педагогів. Pedagogical and psychological sciences: development prospects in countries of Europe at the beginning of the third millennium: Collective monograph. Volume 1. Riga : Izdevnieciba «Baltija Publishing», 2018. C. 241-258.

7. Пілотний етап моніторингового дослідження оцінювання якості освітнього процесу в закладах дошкільної освіти із застосуванням методики ECERS-3 (інформаційний звіт) / кол. авт.: О. Косенчук, I. Новик, О. Венгловська. Київ: Державна установа «Український інститут розвитку освіти», 2021. $21 \mathrm{c.}$

8. Про затвердження плану пріоритетних дій Уряду на 2021 рік: розпорядження КМУ від 24 березня 2021 р. № 276-p. URL: https://www.kmu.gov.ua/npas/pro-zatverdzhennya-planuprioritetnih-dij-uryadu-na-2021-s240321 
9. Проєкт Закону України «Про дошкільну освіту», 2021. URL: http://search.ligazakon.ua/1_doc2.nsf/link1/JI06190A.html

10. Професійний стандарт «Вихователь закладу дошкільної освіти»: Наказ Мінекономіки від 19.10.2021 № 755-21. 2021. URL: https://www.me.gov.ua/Files/GetFile?lang= uk-UA\&fileId=6804b9ce-3985-405e-bc2b-6ec93450add2

11. Професійний стандарт «Керівник (директор) закладу дошкільної освіти»: Наказ Мінекономіки від 28.09.2021 № 620-21. 2021. URL: https://www.me.gov.ua/Files/GetFile?lang= uk-UA\&fileId=617126c6-1ffc-4636-9b4b-3566b2ab285d

12. Слюсарук-Літвін С. Професійно-педагогічна підготовка майбутніх вихователів закладів дошкільної освіти в умовах сьогодення. Acta Paedagogica Volynienses. №2. 2021. С. 22-27. URL: http://journals.vnu.volyn.ua/index.php/pedagogy/article/view/68.

13. Auger, A., Farkas, G., Burchinal, M. R., Duncan, G. J., \& Vandell, D. L. (2014). Preschool center care quality effects on academic achievement: An instrumental variables analysis. Developmental Psychology, 50(12), 2559-2571. http://dx.doi.org/10.1037/a0037995

14. Burchinal, M. (2017). Measuring early care and education quality. Child Development Perspectives, http://dx.doi.org/10.1111/cdep.12260

15. Garvis, S., S. Sheridan, P. Williams, and E. Mellgren. 2017. «Cultural Considerations of ECERS-E in Sweden: A Reflection on Adaption.» Early Child Development and Care 188: 584593. doi: 10.1080/03004430.2017.1377192

16. Sakai, L. M., Whitebook, M., Wishard, A., \& Howes, C. (2003). Evaluating the Early Childhood Environment Rating Scale (ECERS): Assessing the differences between the first and revised versions. Early Childhood Research Quarterly, 18, 427-445. http://dx.doi.org/10.1016/j.ecresq.2003.09.004

\section{References:}

1. Bazovyj komponent doshkiljnoji osvity (Derzhavnyj standart doshkiljnoji osvity) (Basic component of preschool education. (2021). [Basic component of preschool education (State standard of preschool education)]. Retrieved from: https://mon.gov.ua/storage/app/media/rizne/2021/12.01/ Pro_novu_redaktsiyu\%20Bazovoho\%20komponenta\%20doshkilnoyi\%20osvity.pdf [in Ukrainian].

2. Gharms Teljma, Richard M. Klifford, Debbi Krajer. (2020). Scale for assessing the quality of the educational process in preschool institutions. Third edition. (ECERS-3) [Scale for assessing the quality of the educational process in preschool institutions. Third Edition (ECERS-3)] [in Ukrainian].

3. Durmanenko O. (2021). Otsiniuvannia yakosti doshkilnoi osvity yak skladnyk profesiinoi pidhotovky maibutnikh vykhovateliv [Assessing the quality of preschool education as a component of professional training of future educators]. Acta Paedagogica Volynienses. (Vols. 1), (pp. 16-22). Retrieved from: http://journals.vnu.volyn.ua/index.php/pedagogy/article/view/53 [in Ukrainian].

4. Ievropeiska ramka yakosti rannoho rozvytku i doshkilnoi osvity (2019). [European quality framework for early development and preschool education]. Retrieved from: https://eurlex.europa.eu/legal-content/EN/TXT/PDF/?uri=CELEX:32019H0605(01)\&rid=4

5. Ivaniuk, H. I., Venhlovska, O. A., Antypin, Ye. B. (2020). Osobystisno-profesiinyi rozvytok maibutnikh pedahohiv $\mathrm{u}$ protsesi navchalnykh praktyk [Personal and professional development of future teachers in the process of educational practices]. Neperervna profesiina osvita: teoriia i praktyka. (Vols. 2 (63)), (pp. 25-34).

6. Kuzemko L. V., Novyk, I. M. (2018). Suchasni aspekty osobystisno-profesiinoho rozvytku maibutnikh pedahohiv. Pedagogical and psychological sciences: development prospects in countries of Europe at the beginning of the third millennium: Collective monograph. (Vols 1), (pp. 241-258). Riga : Izdevnieciba «Baltija Publishing».

7. Kosenchuk O., Novyk I., Venhlovska O. (2021). Pilotnyi etap monitorynhovoho doslidzhennia otsiniuvannia yakosti osvitnoho protsesu $v$ zakladakh doshkilnoi osvity iz zastosuvanniam metodyky ECERS-3 (informatsiinyi zvit) (2021) [Pilot stage of the monitoring study 
of assessing the quality of the educational process in preschool education institutions using the ECERS-3 methodology (information report)]: Derzhavna ustanova «Ukrainskyi instytut rozvytku osvity».

8. Pro zatverdzhennja planu priorytetnykh dij Urjadu na 2021 rik (2021). [On approval of the Government's priority action plan for 2021]. Retrieved from: https://www.kmu.gov.ua/npas/prozatverdzhennya-planu-prioritetnih-dij-uryadu-na-2021-s240321 [in Ukrainian].

9. Projekt Zakonu Ukrajiny «Pro doshkiljnu osvitu» (2021). [Draft Law of Ukraine "On Preschool Education"]. Retrieved from: http://search.ligazakon.ua/l_doc2.nsf/link1/JI06190A.html [in Ukrainian].

10. Profesijnyj standart «Vykhovatelj zakladu doshkiljnoji osvity» (2021). [Professional standard "Preschool teacher"]. Retrieved from: https://www.me.gov.ua/Files/GetFile?lang=ukUA\&fileId=6804b9ce-3985-405e-bc2b-6ec93450add2 [in Ukrainian].

11. Profesijnyj standart «Kerivnyk (dyrektor) zakladu doshkiljnoji osvity» (2021). [Professional standard "Head (director) of preschool education"]. Retrieved from: https://www.me.gov.ua/ Files/GetFile?lang=uk-UA\&fileId=617126c6-1ffc-4636-9b4b-3566b2ab285d [in Ukrainian].

12. Sliusaruk-Litvin S. (2021). Profesiino-pedahohichna pidhotovka maibutnikh vykhovateliv zakladiv doshkilnoi osvity v umovakh sohodennia [Professional and pedagogical training of future educators of preschool education in today's conditions]. Acta Paedagogica Volynienses. (Vols 2), (pp. 22-27) Retrieved from: http://journals.vnu.volyn.ua/index.php/pedagogy/article/view/68.

13. Auger, A., Farkas, G., Burchinal, M. R., Duncan, G. J., \& Vandell, D. L. (2014). Preschool center care quality effects on academic achievement: An instrumental variables analysis. Developmental Psychology, 50 (12), 2559-2571. http://dx.doi.org/10.1037/a0037995

14. Burchinal, M. (2017). Measuring early care and education quality. Child Development Perspectives, http://dx.doi.org/10.1111/cdep.12260

15. Garvis, S., S. Sheridan, P. Williams, and E. Mellgren. 2017. «Cultural Considerations of ECERS-E in Sweden: A Reflection on Adaption.» Early Child Development and Care 188: 584-593. doi: 10.1080/03004430.2017.1377192

16. Sakai, L. M., Whitebook, M., Wishard, A., \& Howes, C. (2003). Evaluating the Early Childhood Environment Rating Scale (ECERS): Assessing the differences between the first and revised versions. Early Childhood Research Quarterly, 18, 427-445. http://dx.doi.org/10.1016/j.ecresq.2003.09.004 